\title{
Porównanie klasyfikacji zasobów węglowodorów: polskiej, PRMS, UNFC i stosowanej w dokumentowaniu złóż niekonwencjonalnych
}

\begin{abstract}
Przedstawione zostało porównanie polskiej klasyfikacji zasobów węglowodorów z PRMS, UNFC i klasyfikacją zasobów w złożach niekonwencjonalnych (w łupkach), a także ich wzajemne relacje i zakres stosowania. Różny cel tych klasyfikacji powoduje, że nie powinny być one używane zamiennie. Wskazane jest natomiast ich komplementarne stosowanie, wzbogacające informację o stanie znajomości zasobów i możliwości ich wykorzystania.
\end{abstract}

Słowa kluczowe: węglowodory, zasoby, klasyfikacja.

\section{Hydrocarbon resources classification: Polish, PRMS, UNFC and applied to shale gas. A comparison}

The comparison of polish hydrocarbon resources classification system with PRMS, UNFC and applied to unconventional (shale gas) resources was presented. Mutual relations and mode of application was analyzed. Due to different purposes of classification they are not directly exchangeable. However their complementary utilization may allow better presentation of state of knowledge of resources, and the possibilities for their utilization.

Key words: hydrocarbons, resources, classification.

\section{Wprowadzenie}

Nadzieje wiązane z możliwością wykorzystania złóż gazu w łupkach w Polsce i zainteresowanie firm zagranicznych ich poszukiwaniem oraz eksploatacją stwarzają potrzebę przeglądu stosowanych metod dokumentowania i wykazywania ich zasobów. Rodzi to także wątpliwości odnośnie do zasadności używanego w Polsce sposobu klasyfikacji zasobów węglowodorów wobec wymagań w tym zakresie ustalanych w skali międzynarodowej, a w ślad za tym pytanie, czy nie należałoby zmienić stosowanych dotychczas krajowych zasad dokumentowania złóż i przedstawiania ich zasobów.

\section{Idea i podstawy klasyfikacji zasobów}

Na potrzebę klasyfikacji zasobów zwrócono uwagę już na przełomie XIX i XX wieku. Miała być ona środkiem do oceny stopnia ich rozpoznania i związanej z tym skali ryzyka przedsięwzięć górniczych. Od tego czasu jest ona przedmiotem nieustającej dyskusji. Klasyfikacje opracowywane są przez służby geologiczne, kompanie górnicze i organizacje zawodowe. Ich stosowanie jest zwykle wymagane przez instytucje finansujące działalność górniczą, oceniające i kon- trolujące jej bezpieczeństwo z tego punktu widzenia. Zasoby złoża traktowane są jako składnik aktywów przedsiębiorstwa górniczego. Ich ocena i klasyfikacja stanowią podstawę oceny wiarygodności przedsięwzięć inwestycyjnych w górnictwie. Klasyfikacja zasobów jest też wprowadzana aktami prawnymi.

Większość klasyfikacji opiera się na dwóch zasadniczych grupach kryteriów: 
- dokładności (lub wiarygodności) geologicznego rozpoznania złoża i jego zasobów,

- ocenie możliwości eksploatacji złoża i ekonomicznej użyteczności zasobów.

Wprowadza się także podział zasobów w zależności od stopnia zaawansowania inwestycji związanych z ich wykorzystaniem.

Sposób wyróżniania poszczególnych klas i kategorii zasobów według tych kryteriów jest zróżnicowany. Niejednakowa też jest waga przypisywana obu grupom kryteriów podziału w zależności od celu klasyfikacji. Utrudnia to porównywanie różnych klasyfikacji i tłumaczenie terminów określających wyróżniane kategorie, grupy i klasy zasobów w różnych językach. Bezpośrednie, leksykalne tłumaczenie stosowanych pojęć, bez odwołania do ich definicji, prowadzi często do zniekształcenia sensu wyróżnianych jednostek podziału zasobów i błędnego rozumienia ich znaczenia.

Różnorodność klasyfikacji zrodziła potrzebę ich ujednolicenia. Próby takie podejmowano już w latach 30 . XX wieku. Globalizacja działalności inwestycyjnej i trudności porównywania różnych klasyfikacji zasobów stały się podstawą prac w kierunku stworzenia jednolitej ich klasyfikacji, akceptowanej na forum międzynarodowym, i opracowania jednolitej stosowanej terminologii.

Prace takie rozpoczęto w latach 80 . XX wieku w ramach działalności Europejskiej Komisji Gospodarczej ONZ (UNECE) i zintensyfikowano je po 1991 r. [2]. Po wielu latach dyskusji doprowadziły one do stworzenia jednolitej ramowej klasyfikacji zasobów: United Nations Framework Classification of Resources and Reserves (UNFC). Wyróżniane w niej kategorie zasobów oznaczane są symbolami trzycyfrowymi określającymi ocenę ekonomiczną zasobów, stopień zaawansowania prac zmierzających do wykorzystana złoża i stopień rozpoznania geologicznego. Uwalnia to od nieporozumień językowych przy nazywaniu poszczególnych klas i kategorii zasobów.

W przypadku złóż węglowodorów niezależnie została sformułowana klasyfikacja ich zasobów, uzgodniona przez wiodące stowarzyszenia zawodowe związane z ich poszukiwaniem i eksploatacją: Society of Petroleum Engineers - SPE, American Association of Petroleum Geologists - AAPG, World Petroleum Council - WPC, Society of Petroleum Evaluation Engineers - SPEE, Society of Exploration Geophysicists - SEG [6]. Stworzony został jednolity system klasyfikacji zasobów Petroleum Resources Management System - PRMS.

Równolegle prowadzone były prace w kierunku uzgodnienia tej klasyfikacji z międzynarodową ramową klasyfikacją zasobów UNFC, obejmującą zasoby wszystkich kopalin. Zakończone zostały one w 2009 r. opracowaniem zasad porównywania obu klasyfikacji (PRMS i UNFC), jak również zasad porównywania z nimi klasyfikacji wykorzystywanych w poszczególnych krajach (np. bardzo szczegółowej używanej w Norwegii).

\section{Cele klasyfikacji zasobów}

Istota rozbieżności w stosowanych i proponowanych klasyfikacjach zasobów tkwi w różnie ujmowanej hierarchii podstawowych ich celów i wynikających stąd kryteriów podziału zasobów z uwagi na: ocenę ich użyteczności gospodarczej i możliwości wydobycia oraz wiarygodność informacji odnośnie do ich wielkości i wynikającej z tego skali ryzyka przedsięwzięć inwestycyjnych związanych z ich wykorzystaniem. Dane o zasobach złoża i zróżnicowaniu informacji o nich są niezbędne dla:

- przedsiębiorcy - jako podstawa oceny ryzyka nieosiągnięcia spodziewanych efektów ekonomicznych,

- projektanta górniczego - jako podstawa oceny niepewności powodzenia technicznego proponowanych rozwiązań w zakresie eksploatacji złoża i możliwej konieczności ich modyfikacji,

- instytucji finansującej inwestycje górnicze - jako podstawa oceny ryzyka przedsięwzięcia górniczego oraz dla sprawozdawczości finansowej i oceny aktywów przedsiębiorstwa,

- geologa dokumentatora - jako podstawa oceny poprawności interpretacji danych geologicznych odnośnie do bu- dowy złoża, jakości kopaliny i jej zasobów oraz podejmowania decyzji o potrzebie dalszych badań,

- organów administracji państwowej - jako podstawa oceny stanu znajomości bogactw mineralnych kraju i prowadzenia polityki surowcowej.

Tak różnorodnie formułowane cele klasyfikacji powodują, że nacisk kładzie się na różne jej elementy.

Dla geologa dokumentującego złoże oraz organów administracji najważniejszy jest stan znajomości zasobów i ocena wystarczalności ich rozpoznania dla podejmowania decyzji odnośnie do potrzeby ich dalszych badań lub możliwości zagospodarowania złoża. Dokładność rozpoznania budowy złoża jest także istotna dla projektanta górniczego. Duże znaczenie w tym przypadku ma informacja o zasobach geologicznych złoża i ich użyteczności.

Z punktu widzenia przedsiębiorcy i instytucji finansujących inwestycje górnicze najważniejsza jest ilość zasobów kwalifikowanych do wydobycia i ocena dokładności informacji o możliwości ich wykorzystania. Zasoby oraz ocena ich użyteczności dokonywana na podstawie danych geologicznych 
stanowią dla nich tylko pewnego rodzaju tło, które w momencie oceny zasobów wydobywalnych przestaje być przedmiotem zainteresowania.

Oba punkty widzenia są wzajemnie niesprzeczne, ale dotyczą różnych faz określania zasobów, będących podstawą oczekiwanej produkcji górniczej. Są nimi:

- I faza - określenie zasobów geologicznych, które mogą być przedmiotem eksploatacji z uwagi na właściwości naturalne złoża,

- II faza - określenie zasobów, które mogą być przedmiotem eksploatacji w konkretnych warunkach zagospodarowania złoża,

- III faza - określenie zasobów przewidzianych do wydobycia.

Brak zrozumienia różnych funkcji, jakie spełnia klasyfikacja zasobów, jest źródłem dyskusji i wielu nieporozumień. Wynika to również z odmiennych tradycji i form instytucjonalnych szacowania zasobów. W krajach Europy kontynentalnej, w szczególności objętych w przeszłości gospodarką centralnie planowaną, wytworzone zostały znormalizowane formy szacowania i klasyfikacji zasobów jako podstawy do formułowania administracyjnych przyzwoleń na podejmowanie inwestycji górniczych i nadzoru nad ich oceną, sprawowanego przez organy administracji państwowej. W państwach o silnej liberalnej orientacji rynkowej, dominującej w krajach anglosaskich, brak zinstytucjonalizowanego systemu szacowania zasobów, wynikający z zasady wolności gospodarczej, zaowocował dużą swobodą w podejściu do ich oceny i zrodził potrzebę ujednolicenia jej zasad.

Rozmaicie rozumiane cele klasyfikacji są źródłem nieporozumień przy porównywaniu różnych klasyfikacji zasobów i tłumaczeniu stosowanych terminów (tablica 1).

\section{Klasyfikacja polska}

Klasyfikacja zasobów stosowana w Polsce ma uzasadnienie historyczne. Wywodzi się z wymagań gospodarki złożami w warunkach gospodarki centralnie planowanej, gdy kwalifikacja zasobów do określonej kategorii stanowiła podstawę decyzji o podejmowaniu działalności inwestycyjnej. Obecnie wynika z uznania złóż węglowodorów za własność Skarbu Państwa i służyć powinna ocenie zasobów z punktu widzenia oczekiwań odnośnie do możliwości ich wykorzystania. Podstawowe zasady klasyfikacji, dotychczas obowiązujące, sformułowane zostały na początku lat 50. XX wieku [13]. $\mathrm{W}$ obecnie stosowanej formie określane są $\mathrm{w}$ rozporządzeniach Ministra Środowiska w sprawie dokumentacji geologicznej złoża (ostatnie, aktualne: rozporządzenie z dnia 1 lipca 2015 r. w sprawie dokumentacji geologiczno-inwestycyjnej złoża węglowodorów, Dz. U. z 2015 r. poz. 968) oraz Zasadach dokumentowania złóż ropy naftowej, gazu ziemnego oraz metanu z pokładów węgla [12].

Celem klasyfikacji wykorzystywanej w Polsce jest przede wszystkim inwentaryzacja stanu wiedzy o zasobach i ich kwalifikacji do wykorzystania. W złożach węglowodorów główny nacisk położony jest na ocenę zasobów, które teoretycznie kwalifikują się do wydobycia, to znaczy - których wydobycie jest technicznie możliwe i istnieją podstawy do przewidywania, że wydobycie to może być ekonomicznie uzasadnione. Są to zasoby wydobywalne „bilansowe” i tylko takie przedstawiane są w krajowym bilansie zasobów. W złożach zagospodarowanych i przygotowanych do zagospodarowania wyróżnia się w ich obrębie zasoby przemysłowe, to jest te, które mogą być wydobyte w konkretnych warunkach technicznych i ekonomicznych określonych w projekcie zagospodarowania złoża (lub dokumentacji geologiczno-inwestycyjnej).

Tablica 1. Porównanie klasyfikacji zasobów węglowodorów

\begin{tabular}{|c|c|c|c|}
\hline \multirow{2}{*}{$\begin{array}{l}\text { Charakterystyka } \\
\text { klasyfikacji }\end{array}$} & \multicolumn{3}{|c|}{ Klasyfikacja } \\
\hline & Polska & PRMS & Złoża niekonwencjonalne \\
\hline Cel klasyfikacji & $\begin{array}{l}\text { Inwentaryzacja bazy zasobo- } \\
\text { wej kraju. }\end{array}$ & $\begin{array}{l}\text { Ocena gwarancji sukcesu dzia- } \\
\text { łalności inwestycyjnej. }\end{array}$ & $\begin{array}{l}\text { Ocena możliwości wykorzy- } \\
\text { stania zasobów. }\end{array}$ \\
\hline $\begin{array}{l}\text { Podstawowe } \\
\text { kryteria }\end{array}$ & $\begin{array}{l}\text { Ocena stopnia rozpoznania. } \\
\text { Przydatność gospodarcza za- } \\
\text { sobów. }\end{array}$ & $\begin{array}{l}\text { Stopień zaawansowania dzia- } \\
\text { łań dla wykorzystania złoża. } \\
\text { Prawdopodobieństwo sukcesu. }\end{array}$ & $\begin{array}{l}\text { Techniczna i ekonomiczna } \\
\text { możliwość odzysku gazu } \\
\text { (ropy). }\end{array}$ \\
\hline $\begin{array}{l}\text { Podział } \\
\text { zasobów }\end{array}$ & $\begin{array}{l}\text { Kategorie: } \\
\text { perspektywiczne, (progno- } \\
\text { styczne } \mathrm{D}^{*} \text { ), C, B, A. } \\
\text { Zasoby całkowite, } \\
\text { wydobywalne: } \\
\text { bilansowe, } \\
\text { przemysłowe (operatywne*). }\end{array}$ & $\begin{array}{l}\text { Resources** }^{* *} \\
\text { undiscovered (prospective), } \\
\text { discovered: } \\
\text { unrecoverable, } \\
\text { contingent. } \\
\text { Commercial reserves }{ }^{* *} \text {. } \\
\text { Zasoby: nisko, optymalnie } \\
\text { i wysoko oszacowane. }\end{array}$ & $\begin{array}{l}\text { Rodzaje zasobów: } \\
\text { - GIP (OIP); } \\
\text { - TRR; } \\
\text { - ERR; } \\
\text { - EUR. }\end{array}$ \\
\hline
\end{tabular}

\footnotetext{
${ }^{*}$ Formalnie niewyróżniane.

** Terminy w języku angielskim nie mają ścisłych odpowiedników w języku polskim, objaśnienia w tekście.
} 
Tablica 2. Międzynarodowa klasyfikacja zasobów węglowodorów - PRMS (w brzmieniu oryginalnym, objaśnienia w tekście)

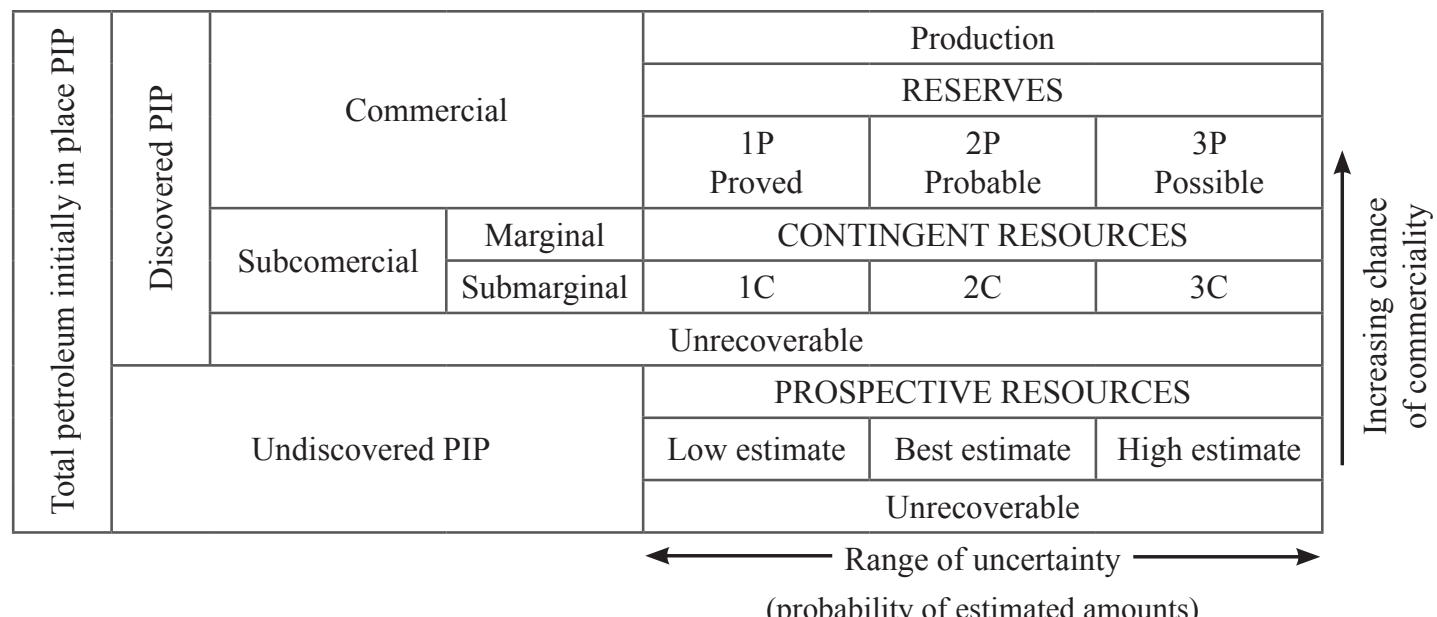

Jeśli przewiduje się możliwość niewykorzystania w czasie eksploatacji całości zasobów przemysłowych (niepełnego ich sczerpania), wówczas wskazane jest wyróżnianie także zasobów operatywnych - równych spodziewanej wielkości całkowitego wydobycia. Zasoby te w Polsce w złożach węglowodorów nie są dotychczas formalnie wykazywane ${ }^{1}$.

Istotną cechę klasyfikacji polskiej stanowi podział zasobów w zależności od stopnia geologicznego rozpoznania. Określają go dwa rodzaje kryteriów: wiarygodność interpretacji budowy geologicznej złoża oraz możliwy błąd oszacowania zasobów ,„દ". Błąd ten określany jest na poziomie ufności 0,9 i wyrażany jako względny w stosunku do wielkości szacowanych zasobów [12]. Wyróżnia się zasoby:

- wstępnie zbadane w kategorii C, z możliwym błędem oszacowania do $50 \%$,

- rozpoznane w kategorii B, z możliwym błędem oszacowania do $35 \%$,

- stwierdzone w kategorii A, z możliwym błędem oszacowania do $20 \%$.

W sposób nieformalny wyróżniane bywają też zasoby prognostyczne, częściowo tylko zbadane, z możliwym błędem ponad 50\%, i zasoby perspektywiczne, tylko domniemane, nieodkryte, co do których przewiduje się, że być może istnieją. Mogą być one oznaczane odpowiednio symbolami D i E [12]. Użycie tych symboli jest wygodne, uwalnia bowiem od nieporozumień, jakie mogą wyniknąć z różnego rozumienia pojęć ,,prognostyczne” i ,perspektywiczne”.

Zasoby wydobywalne bilansowe i przemysłowe ewidencjonowane są w aktualizowanym corocznie krajowym bilansie zasobów [8]. Zasoby perspektywiczne i prognostyczne

\footnotetext{
${ }^{1} \mathrm{~W}$ złożach kopalin stałych ewidencjonowane są całkowite zasoby bilansowe, przemysłowe, a dopiero operatywne określane są jako wydobywalne.
}

wykazywane są w odrębnym bilansie tych zasobów, który jest sporządzany co kilka lat [11].

\section{Klasyfikacja PRMS i jej porównanie z polską}

W klasyfikacji PRMS wyróżnia się zasoby na podstawie dwóch rodzajów kryteriów:

- oceny szans komercyjnego wykorzystania złoża (chance of commerciality),

- prawdopodobieństwa występowania dokumentowanych zasobów (probability of estimated amounts) - jako miary niepewności ich oszacowania.

Wyróżnia się (tablica 2):

- zasoby odkryte (discovered), stwierdzone całkowite, a wśród nich wydobywalne, pomniejszone o niewydobywalne (discovered unrecoverable),

- zasoby nieodkryte, tylko przewidywane, że mogą istnieć (undiscovered prospective resources): potencjalnie wydobywalne i niewydobywalne.

Istotny jest podział zasobów odkrytych, wydobywalnych na:

- zasoby przygotowane do wydobycia lub które są wydobywane (reserves) i stanowią podstawę produkcji spełniającej wymagania rynkowe (commercial),

- zasoby stwierdzone (odkryte), możliwe do wydobycia (contingent resources), którego nie podjęto, ale kwalifikujące się do niego (marginal contingent resources) oraz niekwalifikujące się do niego (submarginal contingent resources).

Podział ten może być porównany w zasadzie z klasyfikacją polską w sposób przedstawiony w tablicy 3. Istotną różnicą jest jednak sposób stosowania klasyfikacji. W polskiej klasyfikacji zasoby przemysłowe stanowią część zasobów bilansowych, w klasyfikacji PRMS resources i reserves są wielkościami rozłącznymi. 
Tablica 3. Podział zasobów według klasyfikacji polskiej i PRMS

\begin{tabular}{|c|c|c|c|}
\hline \multicolumn{3}{|c|}{ Rodzaje zasobów według klasyfikacji } & \multirow{2}{*}{ Uwagi } \\
\hline \multicolumn{2}{|l|}{ PRMS } & polskiej & \\
\hline \multicolumn{2}{|c|}{$\begin{array}{c}\text { Reserves } \\
\text { Discovered commercial }\end{array}$} & Zasoby operatywne* $^{*}$ & $\begin{array}{l}\text { W przybliżeniu mogą to być zasoby przemy- } \\
\text { słowe w złożach, dla których uzyskano konce- } \\
\text { sję na wydobycie kopaliny. }\end{array}$ \\
\hline \multirow{2}{*}{$\begin{array}{l}\text { Contingent resources } \\
\text { discovered } \\
\text { subcommercial }\end{array}$} & Marginal & $\begin{array}{c}\text { Zasoby bilansowe i przemysłowe } \\
\text { w złożach jeszcze niezagospodarowanych }\end{array}$ & $\begin{array}{l}\text { Zasoby bilansowe w złożach niezagospodaro- } \\
\text { wanych, przemysłowe w złożach przygotowy- } \\
\text { wanych do zagospodarowania. }\end{array}$ \\
\hline & Submarginal & $\begin{array}{l}\text { Udokumentowane wydobywalne } \\
\text { pozabilansowe }\end{array}$ & Niekwalifikujące się do eksploatacji. \\
\hline \multicolumn{2}{|c|}{ Undiscovered prospective resources } & Zasoby perspektywiczne & $\begin{array}{l}\text { Tylko przewidywane na podstawie przesłanek } \\
\text { geologicznych. }\end{array}$ \\
\hline
\end{tabular}

*Formalnie niewyróżniane w polskiej klasyfikacji zasobów złóż węglowodorów.

Klasyfikacja PRMS może być stosowana zarówno w odniesieniu do zasobów złóż konwencjonalnych, jak i niekonwencjonalnych.

Dla działalności inwestycyjnej związanej z eksploatacją złóż węglowodorów istotne znaczenie mają zasoby określane jako reserves. Są to zasoby dostatecznie dokładnie rozpoznane, przygotowane do ekonomicznie uzasadnionego wydobycia po spełnieniu wszystkich wymagań formalnych niezbędnych do podjęcia eksploatacji i przewidywane do wydobycia na podstawie udzielonej koncesji.

$\mathrm{Z}$ punktu widzenia geologicznego dokumentowania zasobów istotne znaczenie mają zasoby określane terminem contingent resources - ,warunkowe”. Są to zasoby stwierdzone (rozpoznane) i przewiduje się, że ich eksploatacja może być ekonomicznie uzasadniona. $\mathrm{Z}$ definicji wynika, że odpowiadają one pojęciu ,zasoby bilansowe”, które są wyróżniane w klasyfikacji polskiej (tablica 4). Gdy możliwość ekonomicznie uzasadnionej eksploatacji jest potwierdzona przez projekt ich wydobycia, wyróżniane są - na podobnych zasadach jak „zasoby przemysłowe” w klasyfikacji polskiej - zasoby marginal contingent resources. Zwrócić należy jednak uwagę, że w klasyfikacji PRMS odnoszą się one wyłącznie do złóż niezagospodarowanych. Określane są jako „warunkowe” z punktu widzenia planów podejmowania ich eksploatacji.

Tablica 4. Porównanie definicji zasobów w klasyfikacji polskiej i PRMS

\section{PRMS [6]}

\section{Contingent resources (,„asoby warunkowe")":}

zasoby odkryte, wydobywalne. Ilość węglowodorów, oszacowana na określoną datę, które mogą być potencjalnie wydobywalne ze znanych akumulacji po opracowaniu projektu ich wydobycia, ale aktualnie nie są brane pod uwagę jako obiekt eksploatacji (np. z powodu jednego lub więcej jej ograniczeń).

\section{Marginal contingent resources (,zasoby warunkowe brzeżne"):} znane (odkryte) akumulacje węglowodorów, w odniesieniu do których projekt wydobycia oceniony został jako ekonomicznie uzasadniony lub można w sposób racjonalny oczekiwać, że będzie ekonomicznie uzasadniony, ale jego realizacja jest wstrzymana przez jedno uwarunkowanie lub więcej (np. brak infrastruktury, możliwości sprzedaży itp.).

\section{Submarginal contingent resources (,zasoby warunkowe poza- brzeżne"):}

znane (odkryte) akumulacje węglowodorów, w odniesieniu do których projekt ich wydobycia wykazuje, że nie jest ono ekonomicznie uzasadnione, nawet jeśli uwzględni się możliwość polepszenia warunków ekonomicznych.

\section{Klasyfikacja polska [12]}

\section{Zasoby bilansowe:}

zasoby geologiczne (wydobywalne) złoża lub jego części, którego cechy naturalne określone przez kryteria bilansowości (kryteria definiujące złoże) oraz warunki występowania umożliwiają, przy aktualnym stanie techniki, rozważanie możliwości podjęcia jego eksploatacji.

\section{Zasoby przemysłowe:}

zasoby, które mogą być przedmiotem eksploatacji ekonomicznie uzasadnionej w warunkach określonych przez projekt zagospodarowania złoża (dokumentację geologiczno-inwestycyjną), optymalny z punktu widzenia technicznego i ekonomicznego przy spełnieniu wymagań odnośnie do ochrony środowiska.

\section{Zasoby pozabilansowe:}

Zasoby wydobywalne złoża, których cechy naturalne i warunki występowania powodują, że ich eksploatacja nie jest obecnie możliwa.

\section{Zasoby nieprzemysłowe:}

zasoby złoża, których eksploatacja nie jest uzasadniona w warunkach określonych przez projekt zagospodarowania złoża z przyczyn technicznych, ekonomicznych lub wymagań ochrony środowiska.

" „Warunkowe” z punktu widzenia planów podejmowania ich eksploatacji. 
W klasyfikacji PRMS w zależności od prawdopodobieństwa występowania w każdej grupie zasobów wydobywalnych (odpowiednio: reserves, contingent resources, undiscovered resources) wyróżnia się zasoby:

- nisko oszacowane (low estimate, 1C resources) lub stwierdzone (proved reserves $1 \mathrm{P}$ ), pewne z prawdopodobieństwem 0,9 , że rzeczywiste zasoby mogą być większe,

- najlepiej (optymalnie) oszacowane (best estimate, $2 \mathrm{C}$ resources) lub prawdopodobne (probable reserves $2 \mathrm{P}$ ), przewidywane, prawdopodobne $z$ prawdopodobieństwem 0,5 , że rzeczywiste zasoby mogą być większe,

- wysoko oszacowane (high estimate, 3C resources) lub możliwe (possible reserves $3 \mathrm{P}$ ) z prawdopodobieństwem 0,1 , że rzeczywiste zasoby mogą być większe. Klasyfikacja PRMS nie posługuje się zatem pojęciem „stopnia rozpoznania zasobów”.

Możliwy błąd oszacowania zasobów, którym posługujemy się w klasyfikacji polskiej, jest w przybliżeniu równy różnicy zasobów najlepiej i najniżej oszacowanych wyrażonej w procentach w stosunku do zasobów najlepiej oszacowanych (przy założeniu, że rozkład zasobów jest symetryczny).

Zatem w relacji do klasyfikacji PRMS kategorie zasobów według klasyfikacji polskiej są określone w sposób następujący:

- kategoria D (w polskiej klasyfikacji formalnie niewyróżniana), gdy iloraz zasobów „nisko oszacowanych” przez „najlepiej oszacowane”, „przewidywane” jest mniejszy od 0,5 ;

- kategoria C, gdy iloraz zasobów „nisko oszacowanych” przez „najlepiej oszacowane”, ,przewidywane” mieści się w przedziale: $0,5 \div 0,65$;

- kategoria B, gdy iloraz zasobów „nisko oszacowanych” przez „najlepiej oszacowane”, „przewidywane” mieści się w przedziale: $0,65 \div 0,8$;

- kategoria A, gdy iloraz zasobów „nisko oszacowanych” przez „najlepiej oszacowane”, ,przewidywane” jest większy od 0,8

Relację między polską klasyfikacją i PRMS ilustruje rysunek 1.

W zasadzie podział na kategorie rozpoznania wg klasyfikacji polskiej może być stosowany w odniesieniu do każdej grupy zasobów według klasyfikacji PRMS, to jest zarówno w odniesieniu do reserves, jak i contingent resources. Jednakże w praktyce należy oczekiwać, że określenie reserves może dotyczyć w zasadzie tylko złóż dobrze rozpoznanych, a zatem w kat. A, B, ewentualnie niekiedy $\mathrm{C}$, natomiast w przypadku contingent resources zasoby muszą być tylko stwierdzone, a więc zbadane w kategorii $\mathrm{C}$ lub niekiedy $\mathrm{D}$.

\section{Zasoby węglowodorów w złożach niekonwencjonalnych}

Zainteresowanie zasobami węglowodorów w łupkach, odmienność warunków ich występowania w porównaniu ze złożami konwencjonalnymi, a zarazem trudności i ryzyko w szacowaniu ich wielkości spowodowały stosowanie swoistej ich terminologii (niezależnie od możliwości wykorzystywania klasyfikacji PRMS). Jej istotę stanowi ocena kwalifikacji zasobów z punktu widzenia możliwości ich wydobycia ${ }^{2}$.

W przypadku niekonwencjonalnych złóż węglowodorów istotnym zagadnieniem jest możliwość ich odzysku ze złoża. Jest ona ograniczona przez techniczne możliwości wydobycia i ekonomiczne uwarunkowania. W związku z tym wyróżniane są tu zasoby odpowiednio gazu ziemnego lub ropy naftowej [10]:

- całkowite - gas in place (GIP), oil in place (OIP),

- technicznie wydobywalne - technically recoverable resources (TRR),

- ekonomicznie wydobywalne-economically recoverable resources (ERR),

- gwarantujące ekonomicznie uzasadnione wydobycie - estimated ultimate recovery (EUR),

przy czym: GIP $>>>$ TRR $>$ ERR $>$ EUR.

Tak wyróżniane zasoby oceniane są na każdym etapie badania złoża, nawet na etapie prognozowania zasobów. Stosowane są zatem także w odniesieniu do zasobów perspektywicznych, jako wielkości przewidywane, możliwe przy założeniu, które nie jest weryfikowalne a priori, że one rzeczywiście istnieją. W celu uniknięcia nieporozumień przy stosowaniu tych terminów powinno się zawsze podawać, czy odnoszą się one do zasobów udokumentowanych, czy tylko przewidywanych, ale niestwierdzonych. Zaniedbanie tego prowadzi do poważnych nieporozumień odnośnie do rzeczywistej

${ }^{2}$ Podział ten można też wykorzystywać w odniesieniu do zasobów złóż konwencjonalnych, aczkolwiek nie jest to praktykowane. 
wielkości istniejących zasobów, możliwości ich wykorzystania i oczekiwania korzyści, jakie może ono przynieść.

Zasoby technicznie wydobywalne (TRR) są tożsame z wyróżnianymi w klasyfikacji polskiej wydobywalnymi zasobami bilansowymi. Różnice między podawanymi ich wielkościami mogą być spowodowane przez:

- różne przyjmowane kryteria bilansowości określające techniczne możliwości odzysku węglowodorów, na przykład minimalnej gazonośności łupków, przy której uważa się, że odzysk gazu jest możliwy,

- zakładany możliwy współczynnik sczerpania, przede wszystkim relacji TRR/GIP.

Pojęcie ,zasobów ekonomicznie wydobywalnych” (ERR) odpowiada polskiemu terminowi ,zasoby przemysłowe”, które dają podstawę do przewidywania, że ich wydobycie może być ekonomicznie uzasadnione. Zasoby gwarantujące ekonomiczne wydobycie (EUR) odpowiadają pojęciu ,zasoby operatywne", które w polskiej klasyfikacji zasobów węglowodorów dotychczas nie są wyróżniane.
Porównanie podziału zasobów gazu w złożach niekonwencjonalnych z klasyfikacją polską i PRMS przedstawiają tablice 5 i 6 .

\section{Międzynarodowa klasyfikacja zasobów UNFC}

Różnorodność stosowanych klasyfikacji zasobów stała się podstawą opracowania w ramach działalności Komisji Ekonomiczno-Socjalnej ONZ jednolitej ramowej klasyfikacji: United Nations Framework Classification of Reserves/Reosurces - UNFC [9]. Jej ideą jest stworzenie możliwości porównywania za jej pośrednictwem różnych klasyfikacji zasobów. Podstawę tej klasyfikacji stanowi podział zasobów według trzech kryteriów w trójwymiarowym ortogonalnym układzie współrzędnych:

- oceny gospodarczej (economic, oś E),

- stopnia zaawansowania przygotowań do zagospodarowania złoża (feasibility, oś F),

- stopnia geologicznego zbadania (geological, oś G).

Stosowany jest trójstopniowy podział osi E i F oraz czterostopniowy osi G, przedstawiony na rysunku 2 i w tablicy 6 .

Tablica 5. Podział zasobów z uwagi na możliwość ich wykorzystania

\begin{tabular}{|c|c|c|c|c|}
\hline \multicolumn{2}{|c|}{$\begin{array}{l}\text { Shale gas, shale oil } \\
\text { zasoby udokumentowane } \\
\text { (terminy stosowane także do } \\
\text { zasobów przewidywanych) }\end{array}$} & $\begin{array}{c}\text { Polska } \\
\text { (tylko zasoby } \\
\text { udokumentowane) }\end{array}$ & \multicolumn{2}{|c|}{$\begin{array}{c}\text { PRMS } \\
\text { (tylko zasoby udokumentowane) }\end{array}$} \\
\hline $\begin{array}{l}\text { GIP } \\
\text { OIP }\end{array}$ & $\begin{array}{l}\text { Gas in place } \\
\text { Oil in place }\end{array}$ & $\begin{array}{l}\text { Niewyróżniane }{ }^{* *} \text { (niewy- } \\
\text { kazywane) }\end{array}$ & Total initially in place PIP & \\
\hline TRR & $\begin{array}{l}\text { Technically recov- } \\
\text { erable resources }\end{array}$ & $\begin{array}{l}\text { Wydobywalne w grani- } \\
\text { cach złoża według przy- } \\
\text { jętych kryteriów definiu- } \\
\text { jących złoże (bilansowe) }\end{array}$ & $\begin{array}{c}\text { Contingent resources } \\
\text { (discovered subcommercial) }\end{array}$ & $\begin{array}{l}\text { Zasoby znane, technicznie możliwe do } \\
\text { wydobycia, nieprzewidziane na razie do } \\
\text { zagospodarowania. }\end{array}$ \\
\hline ERR & $\begin{array}{l}\text { Economically reco- } \\
\text { verable resources }\end{array}$ & $\begin{array}{l}\text { Wydobywalne } \\
\text { przemysłowe }\end{array}$ & $\begin{array}{l}\text { Contingent marginal resources } \\
\text { (discovered subcommercial) }\end{array}$ & $\begin{array}{l}\text { Zasoby znane, możliwe do ekonomicz- } \\
\text { nie uzasadnionego wydobycia, nieprze- } \\
\text { widziane na razie do zagospodarowania. }\end{array}$ \\
\hline EUR & $\begin{array}{l}\text { Estimated ultimate } \\
\text { recovery }\end{array}$ & Operatywne & $\begin{array}{c}\text { Reserves } \\
\text { (discovered commercial) }\end{array}$ & $\begin{array}{l}\text { Zasoby stwierdzone. Stwierdzona możli- } \\
\text { wość ekonomicznie uzasadnionego wy- } \\
\text { dobycia i handlowego wykorzystania } \\
\text { w ściśle określonych warunkach zakładu } \\
\text { wydobywczego. }\end{array}$ \\
\hline
\end{tabular}

"Podział może być stosowany odpowiednio do zasobów gazu lub ropy naftowej w łupkach.

${ }^{* *}$ Przedstawiane tylko w dokumentacjach geologicznych złóż, niewykazywane w krajowym bilansie zasobów.

Tablica 6. Podział zasobów z uwagi na stopień rozpoznania

\begin{tabular}{|c|c|c|c|c|}
\hline Shale gas & \multicolumn{2}{|c|}{ Polska } & PRMS & Uwagi \\
\hline \multirow{5}{*}{$\begin{array}{c}\text { GIP, TRR, ERR, EUR } \\
\text { (stwierdzone lub przewidywane) }\end{array}$} & \multicolumn{2}{|c|}{ perspektywiczne } & undiscovered prospective & $\begin{array}{c}\text { przewidywana możliwość } \\
\text { występowania }\end{array}$ \\
\hline & \multirow{4}{*}{ udokumentowane } & $\begin{array}{c}\text { (prognostyczne) } \\
\left(\mathrm{D}^{*}\right) \\
\end{array}$ & $\begin{array}{l}\text { discovered subcommercial } \\
\text { contingent resources }\end{array}$ & stwierdzone występowanie \\
\hline & & $\mathrm{C}$ & \multirow{3}{*}{$\begin{array}{c}\text { discovered } \\
\text { commercial reserves }\end{array}$} & \multirow{3}{*}{$\begin{array}{l}\text { udowodniona możliwość } \\
\text { ekonomicznie uzasadnionej } \\
\text { eksploatacji }\end{array}$} \\
\hline & & B & & \\
\hline & & A & & \\
\hline
\end{tabular}

* Formalnie niewyróżniane. 
Daje to możliwość wyróżniania aż 36 klas zasobów. Wyróżniane klasy zasobów oznaczane są symbolami cyfrowymi według schematu E-F-G, na przykład: 111, 121, 332. Dopuszcza się też bardziej szczegółowe podziały poszczególnych klas w zależności od potrzeb i tradycji krajowych. Użycie symboli cyfrowych uwalnia od różnie rozumianych określeń słownych [7, 9]. Umożliwia też za ich pomocą jednoznaczne wyróżnianie klas zasobów, odmiennie nazywanych w językach narodowych.

Zakwalifikowanie zasobów do właściwej klasy UNFC następuje na podstawie spełnienia wymagań określonych w odpowiednich definicjach wyróżnianych klas E, F i G [5, 9].

Klasyfikacja UNFC w założeniu ma spełniać wymagania stawiane informacjom o zasobach w warunkach gospodarki
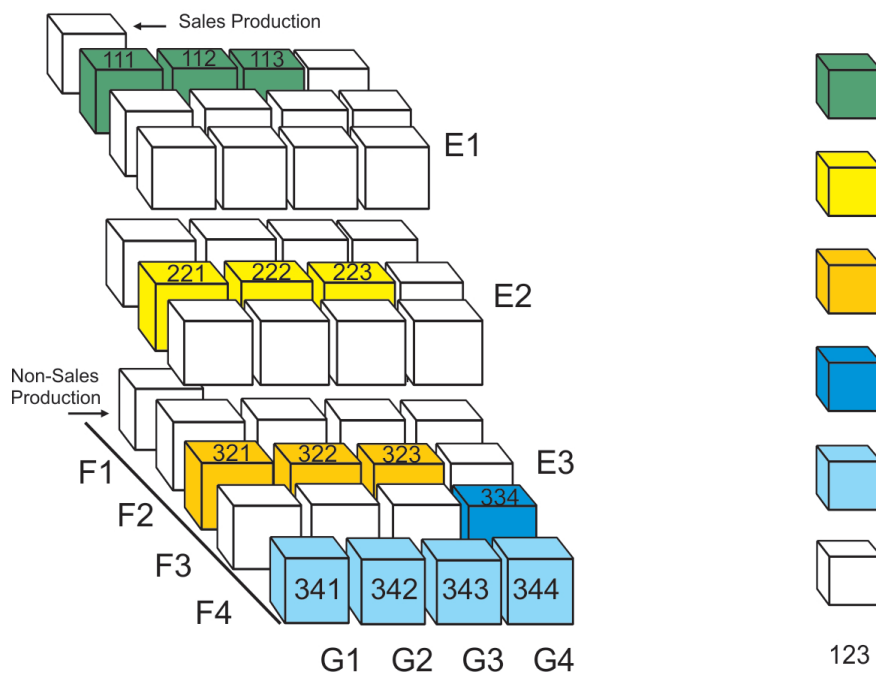

Legenda

Comercial Projects

Potentially Comercia Projects

Non-Comercial Project

Exploration Projects

Additional quantities in place

Combinations not frequenty used

Codification (E1; F2; G3)

Rys. 2. Międzynarodowa klasyfikacja zasobów (UNFC) i najczęściej stosowane klasy zasobów

rynkowej: przez sprawozdawczość finansową oraz przy podejmowaniu inwestycji i ich wspomaganiu przez instytucje kredytujące górnictwo (banki, giełdy).

Tablica 6. Słownik terminów trójwymiarowej międzynarodowej klasyfikacji zasobów (UNFC)

\begin{tabular}{|c|c|c|c|}
\hline \multicolumn{2}{|c|}{ Terminy w wersji oryginalnej } & \multicolumn{2}{|c|}{ Odpowiedniki polskie } \\
\hline \multirow{3}{*}{$\begin{array}{l}\text { Economic } \\
\text { axis } \\
\text { (E) }\end{array}$} & $\begin{array}{l}\text { Economic } \\
\text { (1) }\end{array}$ & \multirow{3}{*}{ Oś oceny gospodarczej } & Spełniające kryteria ekonomiczne \\
\hline & $\begin{array}{l}\text { Potentially economic } \\
\text { (2) }\end{array}$ & & $\begin{array}{c}\text { Potencjalnie spełniające kryteria ekonomiczne } \\
\text { (bilansowe) }\end{array}$ \\
\hline & $\begin{array}{l}\text { Intrinsically economic } \\
\text { (2) }\end{array}$ & & $\begin{array}{l}\text { Mogące spełniać kryteria ekonomiczne (bilan- } \\
\text { sowe i pozabilansowe nierozdzielane) }\end{array}$ \\
\hline \multirow{3}{*}{$\begin{array}{l}\text { Feasibility } \\
\text { axis } \\
\text { (F) }\end{array}$} & $\begin{array}{l}\text { Feasibility study and mining report } \\
\text { (1) }\end{array}$ & \multirow{3}{*}{$\begin{array}{c}\text { Oś stopnia zaawansowania } \\
\text { przygotowań do zagospodaro- } \\
\text { wania złoża }\end{array}$} & $\begin{array}{c}\text { Studium wykorzystywalności złoża (plan ruchu, } \\
\text { biznesplan) }\end{array}$ \\
\hline & $\begin{array}{c}\text { Prefeasibility study } \\
(2)\end{array}$ & & $\begin{array}{c}\text { Wstępna ocena wykorzystywalności złoża (pro- } \\
\text { jekt zagospodarowania złoża) }\end{array}$ \\
\hline & $\begin{array}{c}\text { Geological (opportunity) study } \\
\text { (3) }\end{array}$ & & Ocena geologiczno-gospodarcza złoża \\
\hline \multirow{4}{*}{$\begin{array}{l}\text { Geological } \\
\text { axis } \\
\text { (G) }\end{array}$} & $\begin{array}{l}\text { Detailed exploration } \\
\text { (1) }\end{array}$ & \multirow{4}{*}{$\begin{array}{l}\text { Oś oceny stopnia geologicz- } \\
\text { nego zbadania złoża }\end{array}$} & Rozpoznanie szczegółowe (kat. A + B) \\
\hline & $\begin{array}{l}\text { General exploration } \\
\text { (2) }\end{array}$ & & Rozpoznanie wstępne (kat. C) \\
\hline & $\begin{array}{l}\text { Prospecting } \\
\text { (3) }\end{array}$ & & $\begin{array}{l}\text { Stwierdzenie złoża na podstawie prac poszuki- } \\
\text { wawczych (kat. C, D) }\end{array}$ \\
\hline & $\begin{array}{c}\text { Reconaissance } \\
\text { (4) }\end{array}$ & & $\begin{array}{l}\text { Zasoby przewidywane na podstawie prac reko- } \\
\text { nesansowych }\end{array}$ \\
\hline
\end{tabular}

\section{Wnioski}

Klasyfikacje zasobów węglowodorów: polska, PRMS i stosowana w odniesieniu do złóż niekonwencjonalnych mogą być ze sobą porównywane. Różne ich cele i zasady, na których są oparte, powodują, że nie powinny być one stosowane zamiennie, natomiast mogą się wzajemnie uzupeł- niać. Tam, gdzie jest to uzasadnione, można je wykorzystywać w sposób „równoległy”, odpowiednio do przeznaczenia informacji o zasobach.

W klasyfikacji polskiej w każdej kategorii zasobów mogą być wyróżniane zasoby nisko, przeciętnie i wysoko oszacowane. 
W odniesieniu do kopalin stałych od dawna postulowane jest wyróżnianie zasobów nisko oszacowanych jako ,gwarantowanych" [3, 4], nie znalazło to jednak wyrazu w wymaganiach formalnych odnośnie do dokumentowania zasobów złóż.

W dokumentowaniu złóż węglowodorów w Polsce od kilku lat stosowana jest do szacowania zasobów metoda Monte Carlo [1], a w dokumentacjach geologicznych przedstawiane są zasoby nisko, optymalnie i wysoko oszacowane, zgodnie z zasadami PRMS, niezależnie od oceny kategorii rozpoznania zasobów. O kategorii tej oprócz spełnienia wymagań odnośnie do dokładności oszacowania zasobów decyduje także ogólny stan znajomości budowy złoża i jego parametrów [12], co w klasyfikacji PRMS nie jest ekspono- wane. Zatem stosownie do wiarygodności interpretacji budowy geologicznej złoża można mówić o zasobach nisko, optymalnie i wysoko oszacowanych odpowiednio w kategoriach C, B lub A.

W przypadku zasobów niekonwencjonalnych, w zależności od potrzeb, może być równolegle zastosowana także ich klasyfikacja według zasad PRMS oraz podział na kategorie według klasyfikacji polskiej, na przykład: „TRR (bilansowe), nisko oszacowane w kategorii C”, „ERR (przemysłowe), optymalnie oszacowane w kategorii C" itp.

Wydaje się, że takie uzupełniające się stosowanie klasyfikacji zasobów wzbogaci przekaz informacji o stanie ich znajomości.

Prosimy cytować jako: Nafta-Gaz 2016, nr 9, s. 713-721, DOI: 10.18668/NG.2016.09.05

Artykuł nadesłano do Redakcji 31.03.2016 r. Zatwierdzono do druku 24.05.2016 r.

Praca zrealizowana w ramach projektu „Blue Gas - Polski Gaz Łupkowy”.

\section{Literatura}

[1] Drop K.: Analiza ryzyka przy obliczaniu zasobów gazu ziemnego na przykładzie złoża Babimost. [W:] Metodyka rozpoznawania i dokumentowania złóż kopalin oraz geologicznej obstugi kopalń. Kraków, Wydawnictwo CPPGSMiE, 1998, s. 67-75.

[2] Kelter D.: Classifications Systems for Coal Resources - a Review of the Existing Systems and Suggestions for Improvements. Geol. Jb. 1991, A 127, s. 347-359.

[3] Nieć M.: Analiza statystyczna złóż miedzi monokliny przedsudeckiej. Rudy i Metale Nieżelazne 1964, r. 9, nr 6, s. 300-302.

[4] Nieć M.: Geologia kopalniana. Warszawa, Wydawnictwo Geologiczne, 1990.

[5] Nieć M.: Międzynarodowe klasyfikacje złóż kopalin. Górnictwo i geoinżynieria. Kwart. AGH 2010, r. 34, z. 3, s. 33-49.

[6] Ross J. G.: Petroleum resources definition, classification and categorization guidelines. Guideloned for application of the Petroleum Resources Management System. SPE, AAPG, WPC, SPEE, SEG 2011.

[7] Subelij A.: Draft system of codification of resources/reserves of solid fuels and mineral commodities. Proc. Workshop on Reassessment of Coal and Mineral Deposits under Market Economy Conditions. UNECE - BRG, Hannover 1996, s. $185-188$.

[8] Szuflicki M., Malon A., Tymiński M.: Bilans zasobów złóż kopalin w Polsce. Państwowy Instytut Geologiczny - Państwowy Instytut Badawczy, Warszawa 2015.
[9] UNFC, United Nations International Framework Classification for Reserves/Resources. UN Economic and Social Council, Economic Commission for Europe, Genewa 2009.

[10] Weijermars R., van der Linden J.: Assessing the economic margins of sweet spots on shale gas plays. EAGE First Break 2012, vol. 30, s. 99-106.

[11] Wołkowicz S., Smakowski T., Speczik S.: Bilans perspektywicznych zasobów kopalin Polski. Państwowy Instytut Geologiczny - Państwowy Instytut Badawczy, Warszawa 2011.

[12] Zasady dokumentowania złóż ropy naftowej, gazu ziemnego i metanu w pokładach węla. Ministerstwo Środowiska, Komisja Zasobów Kopalin, Warszawa 2002.

[13] Żółtowski Z.: Przepisy o ustalaniu zasobów złóż kopalin. Warszawa, Wydawnictwo Geologiczne, 1954.

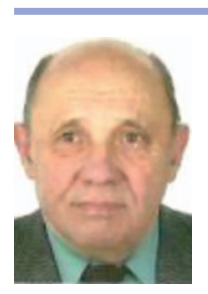

Prof. dr hab. inż. Marek NIEĆ

Instytut Gospodarki Surowcami Mineralnymi

i Energią PAN

Pracownia Geologii Gospodarczej

ul. Wybickiego 7

31-261 Kraków

E-mail:niecm@wp.pl 